\title{
THE ROLE AND PROMOTION OF NURSING
}

\author{
Željka Benceković ${ }^{1}$, Ivica Benko ${ }^{2,3}$, Biserka Režek $^{1}$ and Cecilija Grgas-Bile ${ }^{4}$
}

\begin{abstract}
${ }^{1}$ Directorate of Sestre milosrdnice University Hospital Center, ${ }^{2}$ Clinical Department of Internal Medicine, Sestre milosrdnice University Hospital Center; ${ }^{3}$ University of Applied Health Studies;

${ }^{4}$ Department of Anesthesiology, Resuscitation and Intensive Care, Sestre milosrdnice University Hospital Center, Zagreb, Croatia
\end{abstract}

\begin{abstract}
SUMMARY - Nurses have great influence on health care system. As they face many different states of affairs nowadays, it is necessary to find a way to promote and enable their profession. The significant interaction between nurses and patients and other medical professions makes them a powerful marketing tool of a medical institution. Therefore, the promotion of their image is necessary because of authorizing their professional status. There are numerous ways of creating and improving their image. Some of them include implementation of marketing principles and the Internet as well. This paper presents the web page promotion of nursing, i.e. the Nursing and Related Professions of the Sestre milosrdnice University Hospital Center homepage, as a tool of nursing promotion.
\end{abstract}

Key words: Nursing; Marketing; Perception; Nursing staff, hospital - psychology; Internet; Public opinion

\section{Introduction}

Nurses make up the largest number of employees in health care institutions and, moreover, they spend most of their time in direct contact with patients and their families. They work in various parts of health care institutions and represent a powerful marketing tool of a health care institution ${ }^{1,2}$. They significantly influence the image of medical institutions. They create the image of the health service the patients receive and they have great impact on the position and respect of a health care institution in the community. They can also create the perception of institution and the services provided $^{3,4}$.

Positive experience of patients and their families is the result of a joint action/activity of all members of the health care team. Each individual contributes to the common goal ${ }^{1}$.

Correspondence to: Željka Benceković, RN, BsN, Dipl. ms., Sestre milosrdnice University Hospital Center, Vinogradska c. 29, HR1000 Zagreb, Croatia

E-mail: zeljka.bencekovic@kbcsm.hr

Received June 26, 2015, accepted November 12, 2015
Nurses have the leading role in creating patient satisfaction and appropriate health service in general because of their constant contact with patients. They are highly represented in medical institutions as well. Nurses as part of the professional team contribute to improving the image of the institution. They create a positive working environment and are responsible for patient experience in medical institutions. All team members should collaborate successfully in order to understand and respect their role and the role of their associates ${ }^{1}$.

The lack of nurses in the world has become a serious problem. This problem will be ever more present in the future because of the age structure of nurses leaving the profession and general aging of the population posing a growing need for nursing care ${ }^{5}$. According to the latest projections in the USA, about one million nurses will be needed by $2020^{6}$.

The key recommendations are related to reduction of the possible negative effects caused by the lack of nurses in order to make them aware of the fact how important their image and their position is, which is actually based on the marketing principles ${ }^{7}$. Some authors advocate the usage of internal marketing in order 
to build a positive working environment where nurses are highly motivated and therefore they decide to remain a part of the working process ${ }^{8}$. Researches have shown that job satisfaction and working process affect the partner environment and organizational climate ${ }^{9}$, which are the basic components of internal marketing. Another area considered important for management and marketing refers to motivation to enter the nursing profession ${ }^{10}$.

Recently, the health care market has been increasing, which obliges providers of these services to adjust to market conditions. It also confirms the importance of marketing to promote health care institutions and institution providing services, in which nurses are largely included ${ }^{11}$.

One of the marketing definitions describes it as: "an organizational function and a set of processes aimed at creating, communicating and delivering value to consumers and customer relationship management in a way that favors the organization and its owners"12.

Internal marketing means an organization in which successful communication between the employer and the employees themselves is conducted in order to meet client's needs ${ }^{13}$. The following areas have been proposed: 1) training for marketing; 2) management support; 3) internal communication; 4) human resource management; and 5) inclusion of employees in foreign communication ${ }^{4}$.

Recommendations for improving the image of the nursing profession include the following: connecting with others (professional organizations, community); developing partnerships (with customers, other caregivers); new models of education; maintaining high professional standards; cooperation through all aspects of nursing; use of tools (media, website); and strengthening and development of the nursing profession ${ }^{14}$.

Presentation of nursing on a website is very complex. Some categories that can contribute to the explanation and evaluation of the nursing profession have been determined. These categories are related to the characteristics and role of nurses, their work environment, and the opportunities and resources that are available to them. The role of nurses, their relationship with patients and their families, with the community and other members of the health care team can be visually displayed ${ }^{15}$.

The aim of this paper is to describe the promotion of nursing by the Sestre milosrdnice University Hospi- tal Center website, and efforts to strengthen the nursing profession by clarifying professional roles and the role of nurses in a multidisciplinary team.

\section{Materials and Methods}

The website created by the nurses of the Sestre milosrdnice University Hospital Center, entitled Nursing of the Sestre milosrdnice University Hospital Center, was launched with the help of a few enthusiasts in October 2009 with the aim to present the work of nurses to the public and the development of communication among nurses. A small part of the website contents was dedicated to useful patient information. That website was part of the Hospital website and written in plain HTML (Hyper Text Markup Language). During the four-year period, the page recorded about 41,000 visits (about 925 visits per month on average or 30 visits daily), and 265 different articles were published as well. Given the interface in which the web page was located (plain HTML page), there was no possibility of feedback on page views, browsing, contents, and opinion of visitors, with the exception of the number of visitors.

In June 2013, on the initiative of the working group which had created the first version of the website and the Hospital head nurses, several meetings were held and a new working group of twenty five members currently making up the editorial pages was formed. In addition, members of related professions involved in the work of our related courses regularly held at Sestre milosrdnice University Hospital Center have joined the nurses. Besides nurses, the working group also includes representatives of all departments, of midwives, physical therapists and radiology engineers.

After a few meetings and minor investments, in early October 2013 (exactly four years after the first version of the website), a new site was launched and called Sestre milosrdnice University Hospital Center Nursing - website of nursing and related professions at the Sestre milosrdnice University Hospital Center (Fig. 1).

This web page is divided into several sections:

1. The latest posts, which are updated regularly, editorial board address, link to the Hospital website, webmail and link to the old website Nursing of the Sestre milosrdnice University Hospital Center are located at the top of the homepage. The website has a 

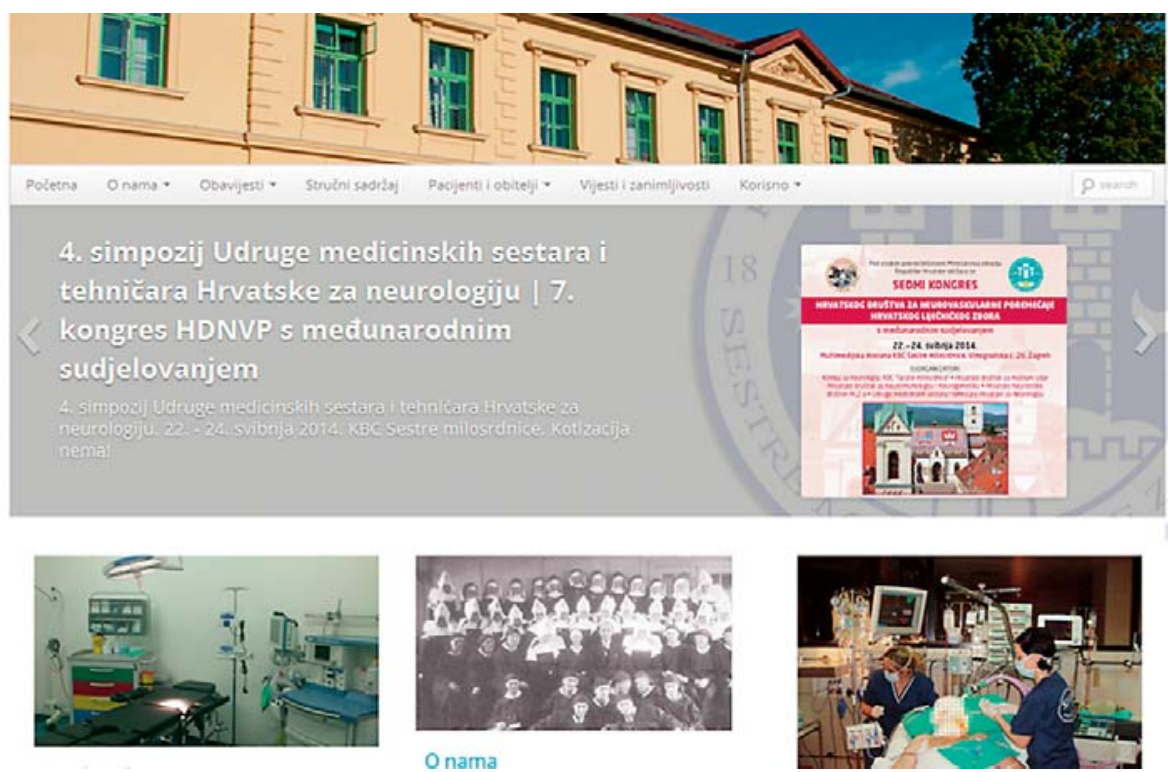

Fig. 1. The Nursing and Related Professions at the Sestre milosrdnice University Hospital Center homepage.

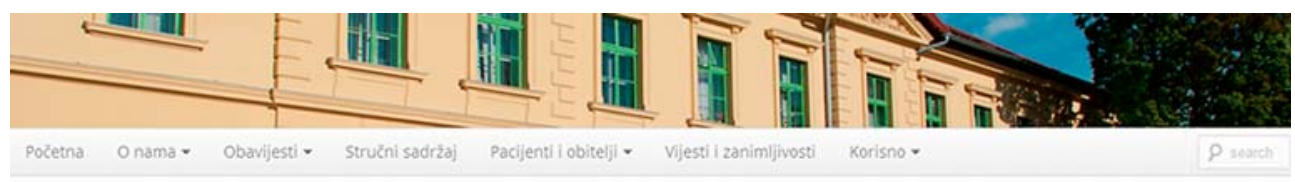

Klinika za pedijatriju - upute roditeljima/skrbnicima
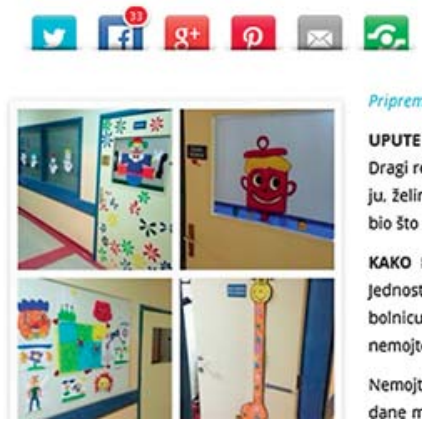

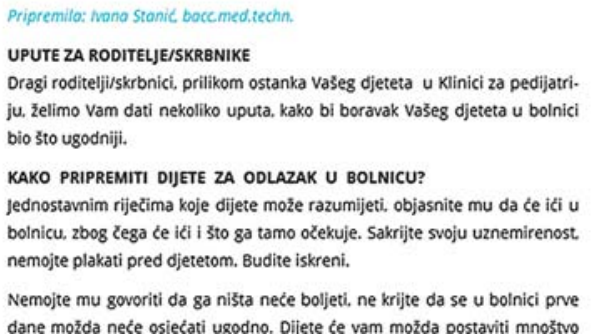

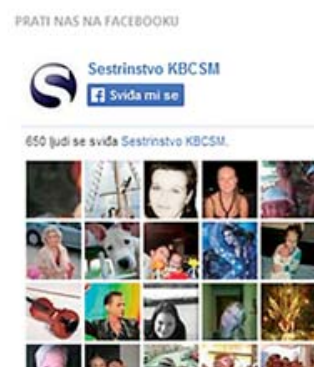

Fig. 2. The section dedicated to patients and their families.

counter, overview of the most popular releases and links to social networks.

2. A section called About Us includes letter of the Hospital head nurse and it is aimed at presenting nursing and related professions.

3. In the Info section, one can find important information published for the Hospital staff and general public, strategic plans for nursing education and interns, and conference calendar.
4. The Professional Activities section is used for reporting from conferences, courses and other events.

5. In the Patients and Family section, there are instructions for users or patients, which are made in accordance with the competence of nurses (Fig. 2).

6. News and Interesting Facts is a section dedicated to publication of news from nursing and health care system in general. There are various activities ini- 
tiated by the Hospital staff and initiatives the staff takes part in.

7. The Useful Hints section gives people quick access to useful links, there is a template for PowerPoint presentation and instructions for publishing contents on the website.

The basic idea of the Editorial Board was to strengthen nursing profession in the Hospital by presenting their role and importance and to present them as part of the interdisciplinary team. In addition, by disclosing and monitoring the webpage contents they can inform each other and communicate more easily.

The new website, much like the first version, has been completely designed and set up by the Editorial Board members, but this time in a modern and highly functional web environment using the so-called CMS (Content Management System), a system that allows dynamic management of the web contents (Fig. 3).

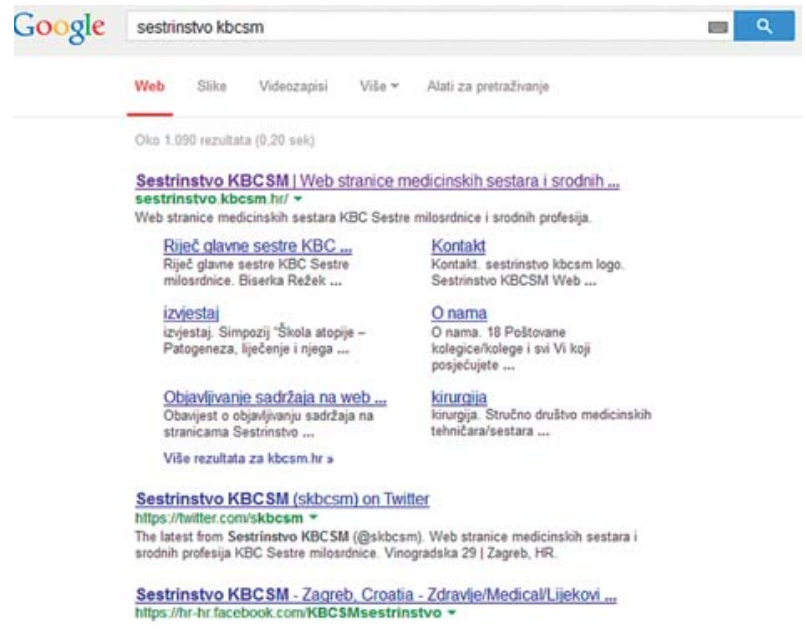

Fig. 3. Access to the Nursing and Related Professions of the Sestre milosrdnice University Hospital Center website.

\section{Results}

In this environment, with the help of a team consisting of a number of related professions, during the first 12 months of its existence, the website recorded around 68,000 hits, which is about 5830 hits per month or 188 per day. Compared to the first version and the four-year period, its daily attendance has increased by $550 \%$. Over the last 3 to 4 months, the interest has been gradually increasing and there have been up to 300 hits per day with the number constantly increas- ing. It is also important to note that around 100 different review articles have been published during the last year.

Given the web environment in which it is located, the new website allows us a more detailed analysis of hits. It can be determined which segment of the contents is visited most frequently, which keywords are accessed, from which countries is the site most accessed, from what kind of devices, and during which weekdays and hours it is most frequently visited.

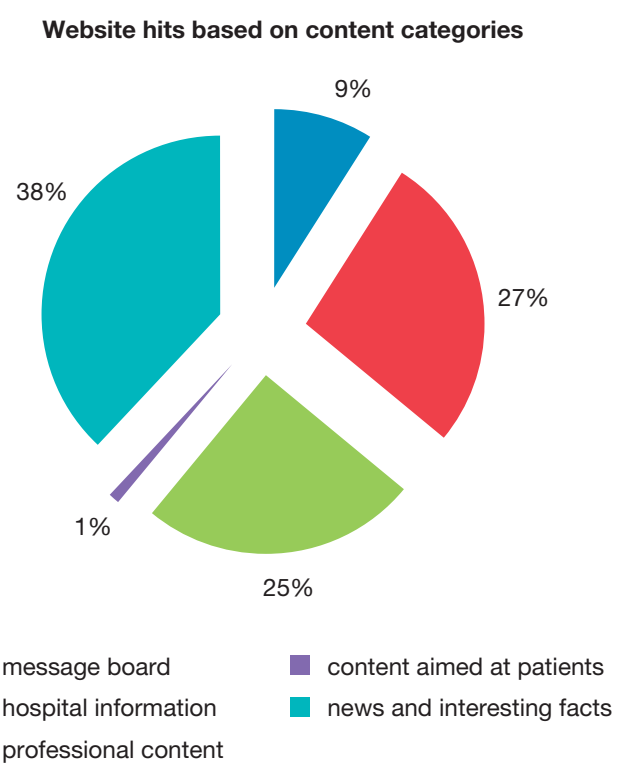

Fig. 4. The contents visited on the webpage.

With the new web environment, it can be seen that nurses are the most numerous visitors since the contents that are most visited are the ones intended for them. Thus, professional contents related to the work of nurses account for 38\% of hits. Topics intended for continuous education and training of nurses in the form of workshops, symposia and conferences rank second with $27 \%$ of hits. Presentations of the work of nurses and related professions at clinical departments and departments account for $25 \%$ of total hits, also ranking high among the most frequently visited contents (Fig. 4).

Analysis of the most searched key words has revealed that there has been an increase in the number of searches about diseases and disorders, as well as diagnostic and other procedures. Therefore, it is concluded that patients make a particular group of visitors. With 
Fig. 5. Website hits according to countries.

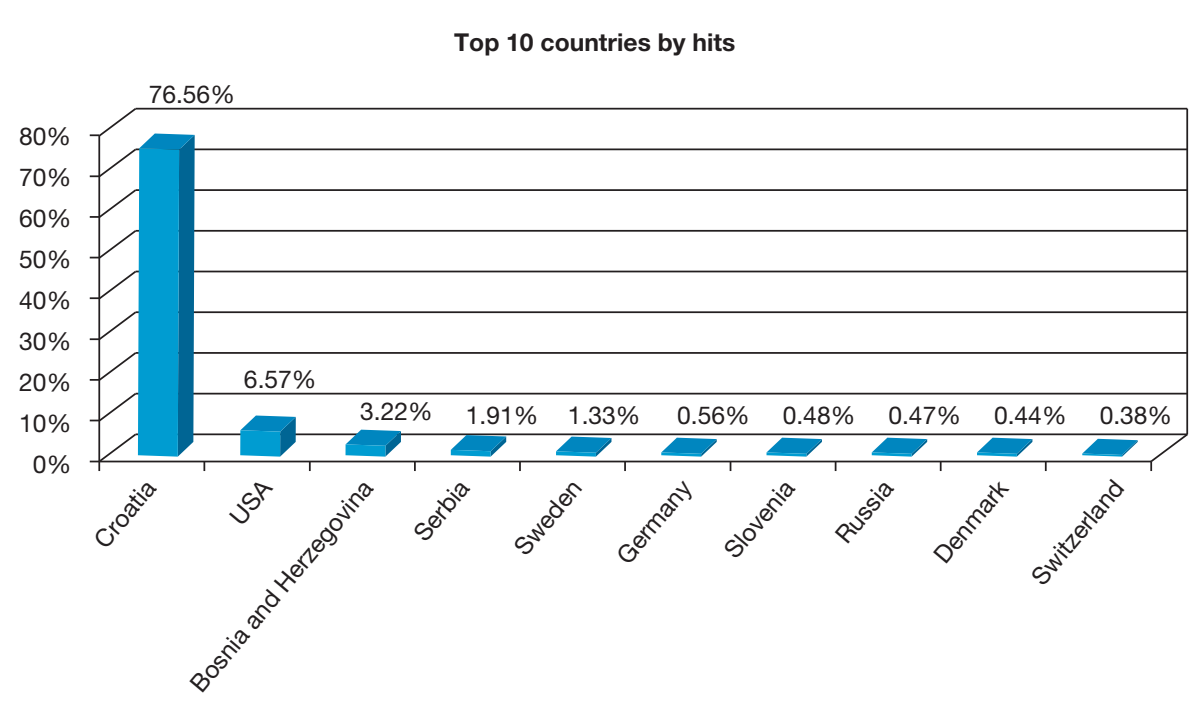

only two review articles published in one year and aimed at patients, there has been an increase of hits by $1 \%$.

The web page is not only accessed from Croatia, but also from the neighboring and other, more distant countries.

Figure 5 shows that the highest number of visitors come from Croatia ( $76.6 \%$ of all hits), but that the web page has also been accessed from the United States (6.6\%), Bosnia and Herzegovina (3.2\%), etc.

Linking the website to popular social networks has further increased the number of visits. Hits on social networks are three times as high as those on the website (Fig. 6).

The highest number of hits was from personal computers (85\%), however, there has been a growing trend in accessing the site via mobile phones and tablets (10.3\%). For this purpose, the website has been optimized for easier viewing on mobile phone and tablet screens.

Data on website hits during weekdays are particularly interesting since it is seen that the site gets most hits on Wednesdays (19\%) and the least on Sundays (8.96\%). Every day, the highest number of hits is recorded between $11 \mathrm{AM}$ and $3 \mathrm{PM}$ (36\%).

The Editorial Board holds meetings at least twice a year or more, when previous activities, results and future plans are discussed. By analyzing data on hits at these meetings, they come up with new ideas and plans. Since, at the moment, the website contains only a small number of contents aimed at patients and their families, the plan is to increase their number. Because

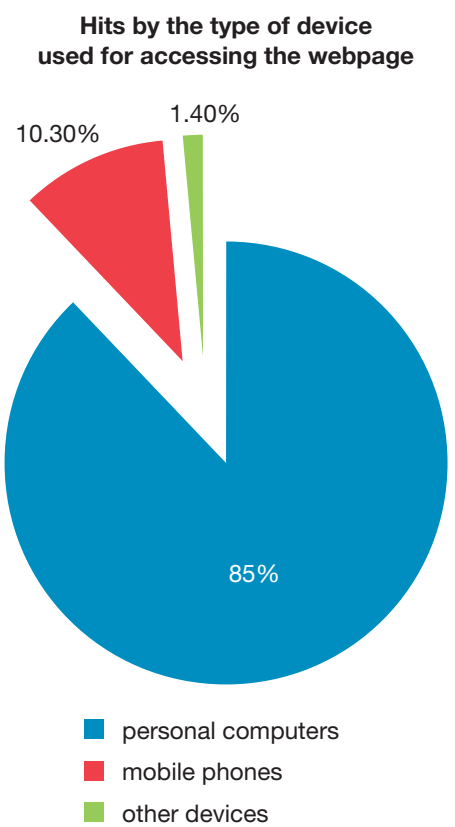

Fig. 6. Website hits according to the point of access.

of the great interest in professional contents and training of nurses, some online courses (so-called webinars) are being developed at the moment, as well as an online magazine of the Sestre milosrdnice University Hospital Center for nurses and related professions. The Editorial Board has also considered the idea of a multilingual website since it is accessed from other countries by speakers of different languages. An online survey that would allow for better interaction with users is being carried out; it will allow the users to give 
their opinions on their satisfaction with the contents, as well as suggestions for improvements.

In other health care institutions in the Republic of Croatia, nurses have also been writing about their profession on websites, but those sites are mostly part of the web pages of the respective health care institution. The Nursing and Related Professions of the Sestre milosrdnice University Hospital Center website is specific because it is located within the website of the Sestre milosrdnice University Hospital Center but is independent from it as it has its own domain. In addition to that, its work includes related professions, and the site is constantly developing in order to meet its users' needs. This is another reason why this webpage is a step forward in the promotion of nursing.

\section{Discussion}

It has been proven that the internal marketing of the work organization can be used to attract and retain employees, as well as to strengthen the commitment to meet the needs of internal and external users ${ }^{17}$. Employees who are more attached to the organization work to show better performance, which is also influenced by their satisfaction at the workplace ${ }^{18}$. Based on patient experience as service users, the administrative structures of health care institutions determine the guidelines for providing services in the best possible way in order to retain the existing and attract new patients since they are aware that patients are increasingly informed about the quality of health care and can choose a health care institution of their choice?

Nurses are of great importance for health care system. They are involved in providing health care delegated by physicians and that is within their competence $^{19}$.

In hospitals, nurses provide health care for 24 hours a day, seven days a week. They assess patient needs, develop health care plans and monitor health care outcomes. They are also greatly responsible for coordination of the overall health care together with other care providers (laboratory, pharmacy, nutrition, and others) and they carry out doctors' orders related to the administration of therapy, diagnosis, etc. At the same time, they are focused on the 'patient focused care' assurance model ${ }^{8}$.

The image of nursing has changed over years and has been influenced by many circumstances (general public, private opinions and attitudes, etc.). There are different ways to create and improve the image of nursing (organizing group negotiations, use of information technology, publications, education, marketing, etc.).

Throughout history, no attention was paid to the promotion of nursing, but the circumstances present in modern health care systems oblige each profession to build and improve its own image.

In order for the profession to achieve and strengthen its status, it must follow public needs and inform the public about its activities. Different communication channels are needed to change the perception of nursing in the public. It is vital to present nursing services, programs and profession to the general public and to promote excellence in nursing and accept nurses as true professionals. To improve their image, nurses should find appropriate ways of evaluating their services. In addition, they need to be professional in their appearance, behavior and contacts with other people at all times.

The greatest responsibility for the development and advancement of their own image is in the hands of nurses and the institutions that represent them. This is achieved by:

- understanding the importance of image and the fact that each nurse is responsible for improving the image of her/his profession;

- their greater involvement in professional organizations because nurse associations have great power;

- ensuring decent wages for nurses;

- activating and informing nurses about political issues;

- documenting all activities carried out by nurses;

- sharing their work experiences in the media;

- getting involved in the community and volunteering;

- ensuring public discussion and education about nursing;

- improving nurse careers, issuing publications and researches, and respecting tradition;

- emphasizing the need for nurses not to be presented as the physician's right-hand men;

- being confident and positive;

- maintaining positive relationships with coworkers and patients; 
- using understandable terminology in communication;

- improving continually; and

- informing users about the responsibility for the 24-hour care ${ }^{11}$.

The attitudes the nurses have toward themselves, their work, as well as their relationships with other members of the health care team may influence the impression of the health care institution the users of healthcare have ${ }^{1}$.

There are situations which negatively affect nurses employed in health care institutions, and thus the functioning of these institutions. The primary reason is 'burnout', which is often present among nurses. It develops due to the lack of support from the people managing the health care system, lack of understanding from their co-workers, too many patients relative to the number of nurses, exclusion of nurses from decision-making, low wages and poor working conditions ${ }^{20}$.

Due to the negative conditions that affect nurses, there are many approaches for reducing their consequences in the health care system. One approach advocates the use of internal marketing to improve work and organizational conditions. This model links nurse job satisfaction and internal programs aimed at building a work environment that would foster strengthening and keeping the nursing staff.

Numerous studies have examined the image of the nursing profession in the public through movies, books, television and advertising ${ }^{21}$. The image promoted on the Internet has a similar and perhaps more significant impact on the public and on the nursing profession ${ }^{15}$.

Browsing through available literature, few texts are found that describe nursing on health care institutions' web sites, and there is little evidence for prescribed contents of those sites. A study that analyzed the websites of 100 state hospitals has shown that only $3 \%$ of hospital websites contain written contents related to nursing ${ }^{22}$.In another study, texts and visual descriptors associated with nursing were developed and compared in different hospitals. They were divided into 10 groups and related to the profession, competence, development, health care quality, recognition, different roles, organization of service, professional development, $\mathrm{co}^{-}$ operation and expertise ${ }^{23}$.
These all are the reasons why people who manage nursing, as well as nursing professionals must design an appropriate website for presenting the image of nursing in public. Shortcomings in the nursing web image can result in misunderstanding of the role of nurses by the users of their services ${ }^{22}$.

The nurses at the Sestre milosrdnice University Hospital Center have also recognized the importance of partnership and promotion of their profession, and in particular the benefits of promotion via the Internet. That is why they have launched and have been developing their own website.

\section{Conclusion}

Because of their strong influence and importance in the health care system, nurses have to continually adapt to the system changes and circumstances. Due to negative trends affecting nursing, it is necessary to keep looking for new methods for strengthening and promoting it. Some of these methods include internal marketing, different models of communication and partnership.

Internal marketing influences positive work environment and employee satisfaction, which has positive effect not only on the employees, their performance and loyalty to the work organization, but on its users as well. There are different ways of developing and improving the nursing profession, the image of nursing and the presentation of the role and importance of nurses to the general public. One way of presenting nursing is through the website.

This paper presents the Nursing and Related Professions of the Sestre milosrdnice University Hospital Center web page, which promotes nursing in a specific way and develops partnership in the work of nurses. This website enables analysis in terms of monitoring public interest in the website contents and its continuous development.

Previous results of the work of this website provide an incentive for nurses to promote their profession, strengthen nursing, develop their profession, but also create a positive work environment with simple and acceptable investments. In that way, they contribute to the nursing profession, but also to the work and reputation of their health care institution. 


\section{References}

1. Hafer JC, Joiner C. Nurses as image emissaries: are role conflicts impinging on a potential asset for an internal marketing strategy? JHCM. 1984;4(1):25-35. Available at: http://www. ncbi.nlm.nih.gov/pubmed/23620580, Accessed May 21, 2014.

2. Montoya ID, Kimball OM. Nursing services: an imperative to health care marketing. JNEP. 2012;2(4):187-93, http://dx.doi. org/10.5430/jnep.v2n4p187

3. Rall MM, Meyer SM. The role of registered nurse in marketing of primary healthcare services, as part of health promotion. $\mathrm{Cu}-$ rations. 2006; 29(1):10-24. PMid: 16817488

4. Conduit J, Mavado FT. How critical is internal customer orientation to market orientation. J Bus Res. 2001;51:11-24.

5. Buerhaus PL, Staiger DO, Auerbach DI. Implications of an aging registered nurse workforce. JAMA. 2000;283:2938-54.

6. Allen $\mathrm{L}$. The nursing shortage continues as the faculty shortage grows. Nurs Econ. 2008;26:35-40.

7. Somers MJ, Finch L, Birnbaum D. Marketing nursing as a profession: integrated marketing strategies to address the nursing shortage. Health Mark Q.2010;27:291-306, http://dx.doi.org/ 10.1080/07359683.2010.495306

8. Galimberti S, Rebora P, Di Mauro S, et al. The SIPI for measuring complexity in nursing care: evaluation study. Int J Nurs Stud. 2011. PMid: 20598691

9. Churchill GA, Neil MF, Orville CW. Organizational climate and job satisfaction in the salesforce. J Mark Res. 1976;13:323-32.

10. Evans M. Nursing students turned away. Modern Healthcare. 2007;37:49-51.

11. Deloughery G. Issues and Trends in Nursing, ${ }^{2 n d}$ Edition. Mosby; 2007. Available at: www.unc.edu/courses/2007spring.../ warner15.PDF
12. Bennett PD. Dictionary of Marketing Terms, $2^{\text {nd }}$ Edition. Chicago: McGraw-Hill, American Marketing Association; 1995.

13. Kelemen M, Papasolomou-Doukakis I. Can culture be changed? a study of internal marketing. Ser Ind J. 2004;24(5):121-35.

14. Peltier J, Pointer L, Schibrowsky L. Internal marketing and the antecedents of nurse satisfaction and loyalty. Health Mark Q. 2008;23:75-108.

15. Kasoff J. How do hospitals represent the image of nursing on their web sites? J Nurs Admin. 2006;36(2):73-8.

16. Schmitt B, Simonson A. Marketing Aesthetics: The Strategic Management of Brands, Identity and Image. New York: Simon \& Shuster; 1997.

17. Bell SJ, Menguc B, Stefani SL. When customers disappoint: a model of relational internal marketing and customer complaints. J Acad Mark Sci. 2004;32(2):112-26.

18. Ching SC, Chang HC. Perceptions of internal marketing and organizational commitment by nurses. J Adv Nurs. 2009;65(1): 92-100, http://dx.doi.org/10.1111/j.1365-2648.2008.04844.x

19. Quelch JA. Hospitals, consumers and advertising. Dimens Health Serv. 1979;56(11):33-5.

20. Leiter MP, Harvie P, Frizzell C. The correspondence of patient satisfaction and nurse burnout. Soc Sci Med. 2009;47(10): 1611-7.

21. Kalisch B, Kalisch P. Changing the Image of Nurse. Boston, Mass: Addison-Wesley; 1978.

22. Carty B, Coughlin C, Kasoff J, Sullivan B. Where is the nursing presence on the medical center's website? J Nurs Admin. 2000; 30:569-70.

23. Kasoff J. Publish doctoral dissertation: the Web Sites' Image of Nursing. New York: Teachers College, Columbia University; 2005.

Sažetak

\section{ULOGA I PROMICANJE SESTRINSTVA}

\section{Ž. Benceković, I. Benko, B. Režek i C. Grgas-Bile}

Medicinske sestre imaju velik utjecaj na zdravstveni sustav. Zbog brojnih okolnosti u kojima se one danas nalaze potrebno je pronalaziti načine za njihovu promociju i osnaživanje sestrinske struke. Značajna interakcija medicinskih sestara s bolesnicima i ostalim zdravstvenim strukama čini ih snažnim marketinškim alatom zdravstvene ustanove, a izgradnja i promocija imidža je neophodna u jačanju statusa struke. Brojni su načini izgradnje imidža struke i preporuke za njegovo unaprjeđenje. Jedan od načina je i korištenje marketinških načela te promocija imidža putem interneta. U radu je prikazana web stranica «Sestrinstvo i srodne profesije KBC Sestre milosrdnice» kao jedno od sredstava za promociju sestrinstva.

Ključne riječi: Sestrinstvo; Marketing; Percepcija; Sestrinsko osoblje, bolničko-psibologija; Internet; Javno mišljenje 